\title{
Saccharomyces cerevisiae commits to a programmed cell death process in response to acetic acid
}

\author{
Paula Ludovico, ${ }^{1,2}$ Maria João Sousa, ${ }^{1}$ Manuel T. Silva, ${ }^{2}$ Cecília Leão ${ }^{1}$ \\ and Manuela Côrte-Real ${ }^{1}$
}

Author for correspondence: Manuela Côrte-Real. Tel: +351253 604314. Fax: +351253678980.

e-mail: mcortereal@bio.uminho.pt

\footnotetext{
1 Centro de Ciências do Ambiente-Departamento de Biologia, Universidade do Minho, Campus de Gualtar, 4719-057 Braga, Portugal

2 Imunologia Comparada, Instituto de Biologia Molecular e Celular (IBMC), 4150-171 Porto, Portugal
}

\begin{abstract}
Recent evidence has revealed the occurrence of an apoptotic phenotype in Saccharomyces cerevisiae that is inducible with oxidative stress. Here, exposure of S. cerevisiae to 20-200 mM acetic acid for $200 \mathrm{~min}$ at pH 3.0 resulted in cell death. Yeast mortality induced by 120-200 mM acid was not inhibited by cycloheximide and was accompanied by ultrastructural alterations typical of necrosis. In contrast, alterations associated with cell death induced by 20-80 mM acetic acid included: (i) cycloheximide-inhibitable chromatin condensation along the nuclear envelope; (ii) exposure of phosphatidylserine on the surface of the cytoplasmic membrane, revealed by the FITC-annexin V reaction; and (iii) the occurrence of DNA strand breaks, demonstrated by the TUNEL assay. These results show that a programmed cell death process sharing common features with an apoptotic phenotype can be induced by acetic acid in $S$. cerevisiae. This observation raises the possibility of this mode of cell death being more generalized in yeasts than previously considered and extended to cell death induced by other stress agents.
\end{abstract}

Keywords: active cell death, apoptosis, yeast, acid stress

\section{INTRODUCTION}

In animal cells, apoptosis, necrosis and atypical cell death have been identified as distinct forms of cell death (Darzynkiewicz et al., 1997). A cell triggered to undergo apoptosis activates a widely described cascade of molecular events, which results in a programmed cell suicide. The occurrence of programmed cell death in unicellular organisms was initially discarded based on the altruistic role attributed to such a cell death process in multicellular organisms. However, cell suicide responses have already been reported in prokaryotic and unicellular eukaryotic cells (Matsuyama et al., 1999). It has also been recognized that the sacrifice of individuals of a population of unicellular organisms can be advantageous to the rest of the population. Hence, by analogy with apoptosis, the term 'phenoptosis' has been proposed to designate programmed cell death of an organism, either multi- or unicellular (Skulachev, 1999a, 2000).

Abbreviations: $\mathrm{PI}$, propidium iodide; ROS, reactive oxygen species; TUNEL, terminal deoxynucleotidyl transferase mediated dUTP nick end labelling.
The reported mechanisms underlying programmed cell death in prokaryotes are different from those involved in apoptosis of animal cells. Examples include mechanisms involved in programmed cell death of plasmid-free segregants, avoiding in this way the survival of bacteria unable to retain the plasmid (Yarmolinsky, 1995; Naito et al., 1995), and programmed cell death of phageinfected Escherichia coli, with the prevention of virus spreading among the bacterial population (Matsuyama et al., 1999; Skulachev, 1999a, 2000). Moreover, programmed cell death in bacteria also plays an important role in developmental processes, such as lysis of the mother cell during sporulation of Bacillus subtilis and lysis of vegetative cells in fruiting body formation of Myxococcus xanthus (Lewis, 2000). In addition, programmed cell death has been reported in unicellular eukaryotic organisms (Ameisen, 1996). The yeast Saccharomyces cerevisiae has been used mainly as a tool to study human apoptosis regulatory proteins and it is not generally accepted to have an endogenous programmed cell death process. However, evidence indicating the presence of some basic features characteristic of an apoptotic phenotype in S. cerevisiae was recently reported (Madeo et al., 1997; Ligr et al., 1998). The 
expression of the anti-apoptotic protein Bcl-2 in $S$. cerevisiae provides antioxidant protection and delays natural death (Longo et al., 1997). Furthermore, it was recently shown in $S$. cerevisiae that depletion of glutathione or exposure to low external doses of $\mathrm{H}_{2} \mathrm{O}_{2}$ triggered the cell into apoptosis, whereas depletion of reactive oxygen species (ROS) or hypoxia prevented apoptosis (Madeo et al., 1999). In addition, an intracellular accumulation of ROS was detected in the cell cycle mutant $c d c 48^{\mathrm{S} 565 \mathrm{G}}$ of $S$. cerevisiae and in yeast cells expressing mammalian Bax. These results allowed the identification of ROS production as a key cellular event common to the known scenarios of apoptosis in yeast and animal cells (Madeo et al., 1999). Recently, it was suggested that the $\operatorname{Rad} 9$ protein of Schizosaccharomyces pombe could be a member of the Bcl-2 protein family, being the first protein of this family identified in yeast (Komatsu et al., 2000). The above evidence has suggested that a programmed cell death process occurs in yeasts and shares some conserved aspects with metazoan apoptosis. Nevertheless, yeast cell death processes are far from being clarified. Characteristic features of cell death patterns in yeast need to be identified in order to provide some insights into the cell death mode(s) in this unicellular eukaryote.

Acetic acid is a normal end product of the alcoholic fermentation carried out by $S$. cerevisiae. This compound is not metabolized by glucose-repressed yeast cells and enters the cell in the undissociated form by simple diffusion. Inside the cell, the acid dissociates and if the extracellular $\mathrm{pH}$ is lower than the intracellular $\mathrm{pH}$, this will lead to intracellular acidification, anion accumulation and inhibition of the metabolic cell activity, namely fermentation/respiration (Leão \& van Uden, 1986; Cássio et al., 1987; Pampulha \& Loureiro, 1989). Moreover, it was shown that in $S$. cerevisiae, under certain conditions, acetic acid compromises cell viability and ultimately results in two types of cell death, high and low enthalpy (Pinto et al., 1989). Previous studies from our laboratory have focused on the assessment by flow cytometry of cell structural and functional changes induced by acetic acid in S. cerevisiae and Zygosaccharomyces bailii (Ludovico, 1999; Prudêncio et al., 1998). However, the process by which the yeast cell dies when injured by acetic acid is unknown.

The aim of the present study was to identify morphological, structural and functional cellular markers that would allow the characterization of the mode(s) of cell death induced by acetic acid in $S$. cerevisiae.

\section{METHODS}

Micro-organism and growth conditions. The yeast Saccharomyces cerevisiae W303-1A (MATa ade2 leu2 his3 trp1 ura3) was used. This organism was maintained on YEPD agar slants containing glucose $(2 \%, \mathrm{w} / \mathrm{v})$, yeast extract $(1 \%, \mathrm{w} / \mathrm{v})$, peptone $(2 \%, \mathrm{w} / \mathrm{v})$ and agar $(2 \%, \mathrm{w} / \mathrm{v})$. In experiments, the yeast cells were subcultured in liquid YEPD medium. The growth experiments were performed in $250 \mathrm{ml}$ flasks containing a 2:1 ratio of air to liquid phase, and incubated on a mechanical shaker (150 r.p.m.) at $26^{\circ} \mathrm{C}$. Cells were grown to mid-exponential phase.

Treatments with acetic acid and inhibition of protein synthesis. Exponential-phase cells were harvested and sus-

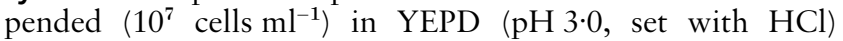
containing $0,20,40,80,120,160$ and $200 \mathrm{mM}$ acetic acid. The treatments were carried out for $200 \mathrm{~min}$ at $26^{\circ} \mathrm{C}$ with magnetic stirring (100 r.p.m.). The inhibition of protein synthesis was performed by adding $100 \mu \mathrm{g}$ cycloheximide (Merck) $\mathrm{ml}^{-1}$ (Barnett et al., 2000) to the cell suspensions at the same time as the different acetic acid concentrations tested. Cycloheximide at this concentration was not cytotoxic after 200 min incubation, as assessed by c.f.u. counts. Viability was determined by c.f.u. counts after $2 \mathrm{~d}$ incubation at $26^{\circ} \mathrm{C}$ on YEPD agar plates. No further colonies appeared after that incubation period. In all the above experiments, the extracellular $\mathrm{pH}$ did not change during the incubations.

Transmission electron microscopy analysis. Cells from different treatment conditions were washed with phosphate/ magnesium buffer $\left(40 \mathrm{mM} \quad \mathrm{K}_{2} \mathrm{HPO}_{4} / \mathrm{KH}_{2} \mathrm{PO}_{4}\right.$, pH 6.5, $0.5 \mathrm{mM} \mathrm{MgCl}_{2}$ ), suspended in $2.5 \%(\mathrm{v} / \mathrm{v})$ glutaraldehyde in $40 \mathrm{mM}$ phosphate/magnesium buffer, $\mathrm{pH} 6 \cdot 5$, and fixed overnight at $4{ }^{\circ} \mathrm{C}$. After fixation, the cells were rinsed twice in $0.1 \mathrm{M}$ phosphate/citrate buffer $(\mathrm{pH} 5.8)$ and suspended in this buffer containing $10 \mathrm{U}$ lyticase (Boehringer Mannheim) $\mathrm{ml}^{-1}$ for about $90 \mathrm{~min}$ at $37^{\circ} \mathrm{C}$, to digest the cell wall. After cell wall digestion of the pre-fixed yeast cells, protoplasts were washed and postfixed with $2 \%(\mathrm{w} / \mathrm{v})$ osmium tetroxide $(2 \mathrm{~h})$ followed by $30 \mathrm{~min}$ incubation with $1 \%(\mathrm{w} / \mathrm{v})$ aqueous uranyl acetate. Dehydration was performed as described by Byers \& Goetsch (1991) for embedding vegetatively grown yeast cells. After $100 \%$ ethanol washes, the samples were transferred to $100 \%$ propylene oxide, and infiltrated with $50 \%(\mathrm{v} / \mathrm{v})$ propylene oxide and $50 \%(\mathrm{v} / \mathrm{v})$ Epon (TAAB Laboratories) for $30 \mathrm{~min}$ and with $100 \%$ Epon overnight. Cells were transferred to gelatin capsules with $100 \%$ Epon and incubated at $60{ }^{\circ} \mathrm{C}$ for $48 \mathrm{~h}$ before cutting thin sections and staining with uranyl acetate and lead acetate. Micrographs were taken with a Zeiss EM 10C electron microscope. For quantitative assessment of yeast cells with condensed chromatin, at least 50 yeast cells with nuclear profiles were counted per sample.

Terminal deoxynucleotidyl transferase mediated dUTP nick end labelling (TUNEL) and propidium iodide staining. DNA strand breaks were demonstrated by TUNEL with the 'In Situ Cell Death Detection Kit, Fluorescein', from Boehringer Mannheim. This technique labels free $3^{\prime}-\mathrm{OH}$ termini with FITC-labelled deoxyuridine triphosphate (dUTP), which was detected by epifluorescence microscopy. Yeast cells were fixed with $3.7 \%$ (v/v) formaldehyde as described by Madeo et al. (1999) and cell walls were digested with lyticase (as above, for $105 \mathrm{~min}$ ). Cytospins of the cell suspensions were made using a Shandon Cytospin 2 cytocentrifuge, operating at 1500 r.p.m. for $5 \mathrm{~min}$. The slides were rinsed with PBS, incubated in permeabilization solution $(0 \cdot 1 \%, \mathrm{v} / \mathrm{v}$, Triton $\mathrm{X}-100$ and $0 \cdot 1 \%, \mathrm{w} / \mathrm{v}$, sodium citrate) for $2 \mathrm{~min}$ on ice, rinsed twice with PBS and incubated with $10 \mu \mathrm{l}$ TUNEL reaction mixture, containing terminal deoxynucleotidyl transferase and FITCdUTP, for $60 \mathrm{~min}$ at $37^{\circ} \mathrm{C}$. Finally the slides were rinsed three times with PBS and a coverslip was mounted with a drop of anti-fading agent Vectashield (Molecular Probes) and with $2 \mu \mathrm{l}$ of a propidium iodide (PI; Molecular Probes) working solution $\left(50 \mu \mathrm{g} \mathrm{ml}^{-1}\right)$ in Tris buffer $(10 \mathrm{mM}, \mathrm{pH} 7 \cdot 0)$ with $\mathrm{MgCl}_{2}(5 \mathrm{mM})$ and RNase $\left(0.5 \mu \mathrm{g} \mathrm{ml}^{-1}\right)$. Observations were carried out using a Zeiss Axioskop epifluorescence microscope equipped with a HBO-100 mercury lamp, filter set 40 (BP360/51, BP485/17, BP560/18) from Zeiss, excitation filter 
BP 450-490, beam splitter FT510 and emission filter LP520. Images were acquired with a Spot 2 camera (Diagnostic Instruments). For the quantitative assessment of TUNEL staining, 50-700 cells were counted per sample.

Annexin V staining. Phosphatidylserine exposure was detected by an FITC-coupled annexin $\mathrm{V}$ reaction with the ApoAlert Annexin V Apoptosis kit (CLONTECH Laboratories), essentially as described by Madeo et al. (1999). Cells were harvested and washed with sorbitol buffer (1.2 M sorbitol, $0.5 \mathrm{mM} \mathrm{MgCl}_{2}, 35 \mathrm{mM} \mathrm{K}_{2} \mathrm{HPO}_{4}, \mathrm{pH} \mathrm{6.8)}$. Cell walls were digested with $15 \mathrm{U}$ lyticase (Sigma) $\mathrm{ml}^{-1}$ and $2 \%(\mathrm{v} / \mathrm{v})$ glusulase (NEE-154 Glusulase; NEN) in sorbitol buffer for about $30 \mathrm{~min}$ at $28^{\circ} \mathrm{C}$; digestion with the two enzymes was monitored by phase-contrast microscopy in order to prevent damage to the unfixed protoplasts. Cells were then washed twice with binding buffer $(10 \mathrm{mM}$ HEPES/ $\mathrm{NaOH}, \mathrm{pH} 7 \cdot 4$, $140 \mathrm{mM} \mathrm{NaCl}, 2 \cdot 5 \mathrm{mM} \mathrm{CaCl}_{2}$; CLONTECH Laboratories) containing $1.2 \mathrm{M}$ sorbitol. To $38 \mu \mathrm{l}$ cell suspension in binding/ sorbitol buffer were added $2 \mu \mathrm{l}$ annexin $\mathrm{V}\left(20 \mu \mathrm{g} \mathrm{ml}^{-1}\right)$ and $2 \mu \mathrm{l}$ of a PI working solution (as described for the TUNEL reaction) and incubated for $20 \mathrm{~min}$ at room temperature. The cells were then washed and resuspended in binding/sorbitol buffer. Finally the slides with coverslips were mounted with the cell suspensions. Microscope settings and image acquisitions were as described above for the TUNEL technique. For quantitative assessment of annexin V-PI staining, at least 150 yeast cells were counted per sample.

Reproducibility of the results. All the experiments were repeated at least three times. The data reported for c.f.u. counts are mean values and standard deviations. Quantitative data for annexin V and TUNEL staining and for chromatin condensation are from one representative experiment; while absolute data were not comparable in these experiments performed on different days, the trends described were fully consistent in the independent experiments.

\section{RESULTS}

Exposure of $S$. cerevisiae strain W303-1A to acetic acid at different concentrations (20-200 mM), pH 3.0, resulted in cell death (Fig. 1). The percentage of survival, estimated by c.f.u. counts after $200 \mathrm{~min}$ treatment, decreased with increasing concentrations of the acid in

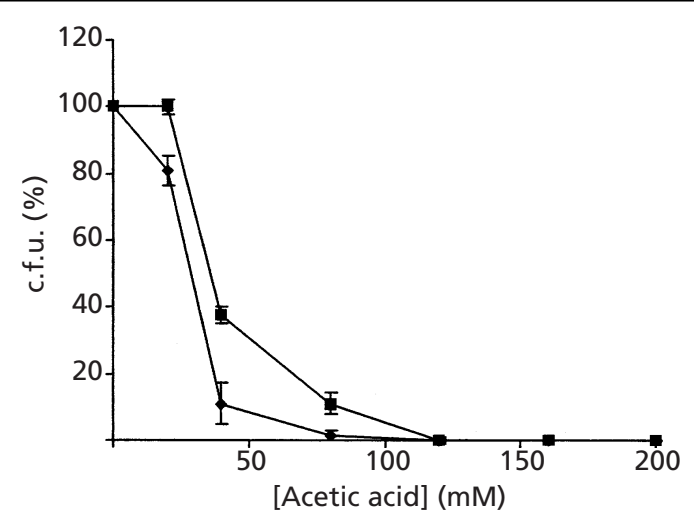

Fig. 1. Relative survival (\% of c.f.u. on YEPD agar plates; $100 \%$ corresponds to the number of c.f.u. at time zero) of $S$. cerevisiae incubated for $\mathbf{2 0 0}$ min with acetic acid in the absence $(\bullet)$ or presence $(\boldsymbol{\square})$ of cycloheximide. Vertical error bars represent standard deviations.
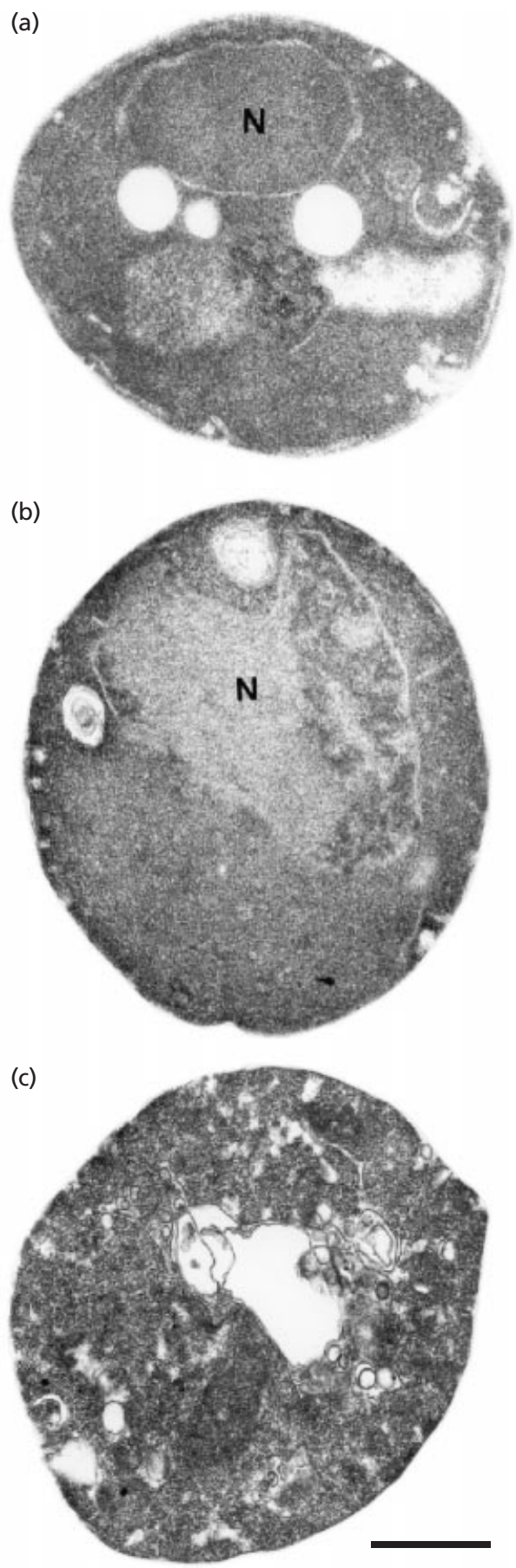

Fig. 2. Electron micrographs of exponentially growing cells of S. cerevisiae. (a) Untreated control, (b) cell treated with $40 \mathrm{mM}$ and (c) cell treated with $160 \mathrm{mM}$ acetic acid for $200 \mathrm{~min}$. N, Nucleus. Bar, $1 \mu \mathrm{m}$.

the extracellular medium. In order to address whether cell death induced by acetic acid treatment was an active process, the same experiments were carried out in the presence of cycloheximide. The presence of this inhibitor of protein synthesis attenuated the toxic effects of acetic acid and enhanced the survival percentage (Fig. 1). However, the protective effect of cycloheximide was 
Table 1. Cycloheximide inhibits chromatin condensation induced in S. cerevisiae by exposure to $20-120 \mathrm{mM}$ acetic acid for $200 \mathrm{~min}$

The percentage of yeast cell profiles with chromatin condensation along the nuclear envelope was determined by counting at least 50 cell profiles per sample. The values in samples exposed to acetic acid in the presence of $100 \mu \mathrm{g}$ cycloheximide $\mathrm{ml}^{-1}$ are given in parentheses. ND, Not determined.

\begin{tabular}{|cc|}
\hline $\begin{array}{l}{[\text { Acetic acid }]} \\
(\mathbf{m M})\end{array}$ & $\begin{array}{c}\text { Chromatin condensation } \\
(\%)\end{array}$ \\
\hline 0 & $0(0)$ \\
20 & $\mathrm{ND}$ \\
40 & $78 \cdot 0(4 \cdot 8)$ \\
80 & $73 \cdot 6(30 \cdot 0)$ \\
120 & $9 \cdot 7(1 \cdot 2)$ \\
160 & $0(0)$ \\
200 & $0(0)$ \\
\hline
\end{tabular}

observed only for the lower acid concentrations; for concentrations higher than $120 \mathrm{mM}$ the survival percentages were not significantly increased by the drug. In fact, a very high mortality was seen in yeasts exposed to $120 \mathrm{mM}$ acid regardless of the presence of cycloheximide (99.86 and $99.90 \%$, with and without the inhibitor, respectively). This indicates that the cell death process induced at the higher concentrations was not dependent on protein synthesis.

Subsequently, it was attempted to characterize further the type of cycloheximide-inhibitable cell death induced by acetic acid at the lower acid concentrations. Thus, samples of cell suspension treated with the acid were harvested and assayed for different apoptotic markers, namely chromatin condensation along the nuclear envelope, exposure of phosphatidylserine at the outer surface of the plasma membrane and formation of DNA strand breaks.

Extensive chromatin condensation along the nuclear envelope in cells treated with $20-80 \mathrm{mM}$ acetic acid (shown in Fig. 2b for $40 \mathrm{mM}$ ) was revealed by quantitative transmission electron microscopy analysis (Table 1), whereas nuclei of untreated cells were homogeneous in shape and density (Fig. 2a). Only a low
Table 2. Characterization of $S$. cerevisiae cells (\%) according to FITC-coupled annexin $\mathrm{V}$ and PI staining after exposure to $20-120 \mathrm{mM}$ acetic acid for $200 \mathrm{~min}$

\begin{tabular}{|lrrrr|}
\hline Cell category* & \multicolumn{4}{c|}{ [Acetic acid] (mM) } \\
\cline { 2 - 5 } & $\mathbf{2 0}$ & $\mathbf{4 0}$ & $\mathbf{8 0}$ & $\mathbf{1 2 0}$ \\
\hline Annexin V (-), PI (-) & $86 \cdot 6$ & $47 \cdot 1$ & $10 \cdot 1$ & $0 \cdot 0$ \\
Annexin V (+), PI (-) & $12 \cdot 5$ & $40 \cdot 4$ & $40 \cdot 7$ & $14 \cdot 7$ \\
Annexin V (+), PI (+) & $0 \cdot 9$ & $12 \cdot 5$ & $43 \cdot 5$ & $41 \cdot 1$ \\
Annexin V (-), PI (+) & $0 \cdot 0$ & $0 \cdot 0$ & $5 \cdot 7$ & $44 \cdot 2$ \\
\hline
\end{tabular}

*Cell category as defined in Results.

percentage of cells treated with $120 \mathrm{mM}$ acid, and no cells treated with 160 or $200 \mathrm{mM}$, exhibited chromatin condensation (Table 1). Consistent with the enhancement by cycloheximide of the survival of $S$. cerevisiae to $40-80 \mathrm{mM}$ acetic acid treatment, a decrease in the number of cells with chromatin condensation along the nuclear envelope was evident in the presence of cycloheximide (Table 1).

However, in many yeast cells treated with $120 \mathrm{mM}$ acetic acid and in most cells treated with $160 \mathrm{mM}$, alterations typical of necrosis were observed by electron microscopy, namely an extensive cell disorganization with most intracellular structures destroyed (shown in Fig. 2c for $160 \mathrm{mM}$ ).

In yeasts, as in mammalian cells, phosphatidylserine has an asymmetric distribution in the lipid bilayer of the cytoplasmic membrane (Cerbón \& Calderón, 1991). The exposure of phosphatidylserine at the outer surface of the cytoplasmic membrane occurs at the early stages of apoptosis (Martin et al., 1995) when membrane integrity is still retained. Therefore, with the technique used in the present study, which includes simultaneous staining with FITC-coupled annexin V and the membrane impermeant fluorochrome PI, those early apoptotic cells only stain green, from FITC, indicating the presence of phosphatidylserine at the outer surface of the plasma membrane [annexin $\mathrm{V}(+)$, PI $(-)$, shown in Fig. 3a for $20 \mathrm{mM}$ acetic acid]. Numbers of annexin $\mathrm{V}$ $(+)$, PI $(-)$ cells were maximal at $40-80 \mathrm{mM}$ acetic acid (Table 2). Yeast cells in more advanced apoptotic stages, or necrotic cells, stain green and red due to the inability
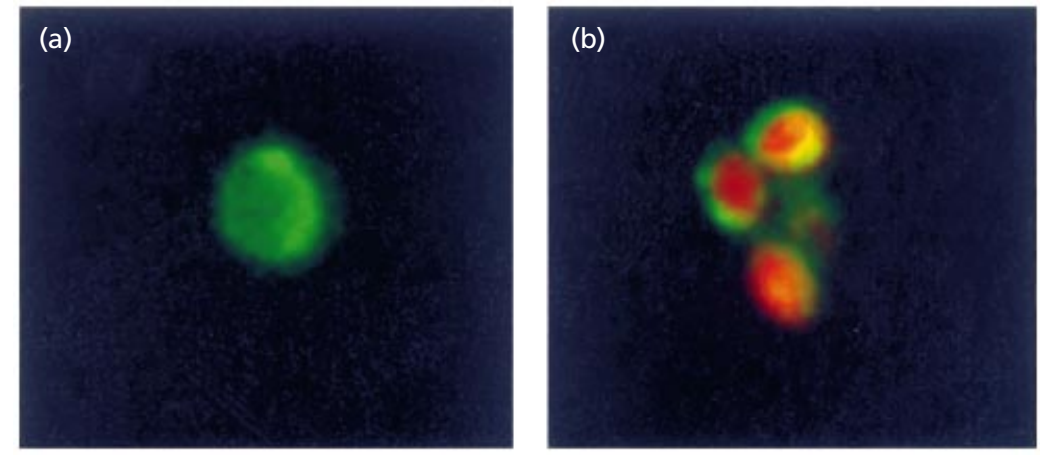

Fig. 3. Annexin V-PI staining of $S$. cerevisiae exponentially growing cells exposed to 20 (a) or 120 (b) $\mathrm{mM}$ acetic acid for $200 \mathrm{~min}$. The cell in Fig. 3(a) is stained only in green by annexin $\mathrm{V}$ [annexin $\mathrm{V}(+)$ ], and not in red $[\mathrm{PI}(-)]$, indicating that it is in an early stage of apoptosis. In contrast, the cells in Fig. 3(b) are stained in both green [annexin $\mathrm{V}(+)$ ] and red $[\mathrm{PI}(+)]$, indicating that they are in advanced apoptosis or in necrosis. 

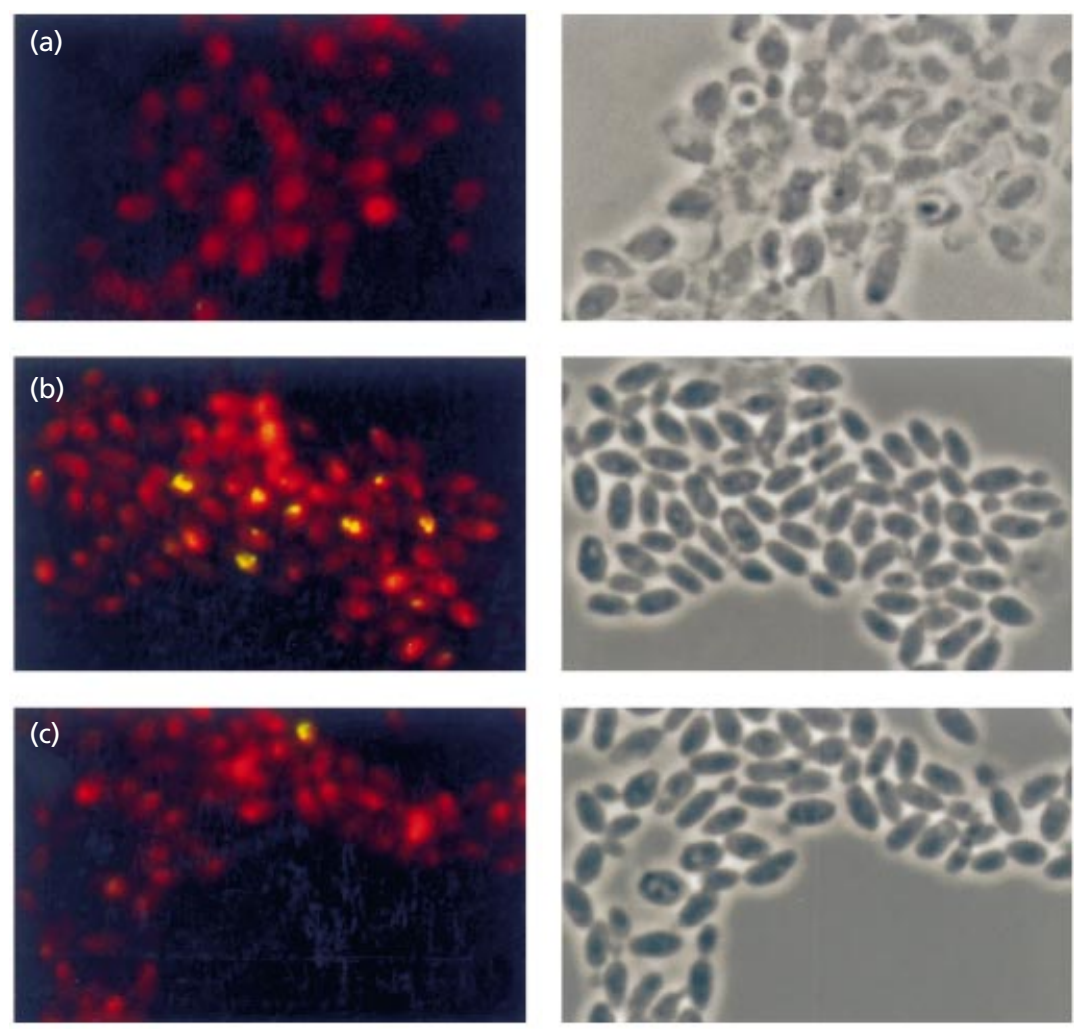

Fig. 4. Left panel: TUNEL reaction after $200 \mathrm{~min}$ of treatment of exponentially growing $S$. cerevisiae cells with 0 (a), 40 (b) or 120 (c) $\mathrm{mM}$ acetic acid. Right panel: phase-contrast of the fields in the left panel. of the cell membrane to exclude PI [annexin V $(+)$, PI $(+)$, shown in Fig. $3 \mathrm{~b}$ for $120 \mathrm{mM}$ acid]. Numbers of annexin $\mathrm{V}(+)$, PI $(+)$ cells were maximal at 80 and $120 \mathrm{mM}$ acetic acid (Table 2). In the $120 \mathrm{mM}$ sample, most of the annexin-V-negative cells were PI-positive [annexin $\mathrm{V}(-)$, PI $(+)$ ]. Untreated cells did not exhibit a positive annexin $\mathrm{V}$ reaction or PI staining [annexin $\mathrm{V}$ $(-)$, PI $(-)]$.

Treatment of $S$. cerevisiae with 20,40 and $80 \mathrm{mM}$ acetic acid resulted in a TUNEL-positive phenotype (yellow nuclear fluorescence as the result of superimposition of green and red fluorescence due to simultaneous staining with TUNEL and PI, as shown in Fig. $4 \mathrm{~b}$ for $40 \mathrm{mM}$ ), indicating the occurrence of DNA strand breaks. The percentage of cells displaying a positive TUNEL staining increased with the acetic acid concentration $(19.0 \%$ and $51.5 \%$ of TUNEL-positive cells were counted in preparations treated with 40 and $80 \mathrm{mM}$ acid, respectively). With $120 \mathrm{mM}$ acetic acid, a few cells $(5.7 \%)$ showed a positive TUNEL reaction (Fig. 4c). Incubation with acetic acid concentrations from 160 to $200 \mathrm{mM}$ resulted in no detectable TUNEL staining. Control cells maintained in YEPD medium, $\mathrm{pH} 3 \cdot 0$, for $200 \mathrm{~min}$ in the absence of acetic acid showed a negative TUNEL staining (Fig. 4a).

For reasons not yet completely understood, cells exposed to cycloheximide (with or without acetic acid) and then stained by the annexin V or TUNEL reactions displayed a bright yellow fluorescent background that made it impossible to analyse the effect of the inhibitor on the two apoptotic markers.
Preliminary results have shown that the apoptotic markers referred to above are present, in a concentration-dependent way, in samples exposed to 20-120 $\mathrm{mM}$ acetic acid for time periods shorter than the $200 \mathrm{~min}$ used in the present study.

\section{DISCUSSION}

Although inhibitors of protein synthesis may, in some cases, prevent the anti-apoptotic cascade (Skulachev, $1999 \mathrm{~b})$, it has been reported that in many cell types apoptosis can be prevented by the inhibition of protein synthesis (Hiraoka et al., 1997; Sánchez et al., 1997). Recently, it was described in $S$. cerevisiae that cycloheximide prevented the apoptotic effects of $\mathrm{H}_{2} \mathrm{O}_{2}$ (Madeo et al., 1999). In the present study, it is shown that, in this species, exposure to $20-80 \mathrm{mM}$ acetic acid for 200 min induces a programmed cell death pathway that requires the functionality of the protein synthesis machinery. This conclusion was based on the observation that cycloheximide inhibited cell death induced by acetic acid at that low concentration range but not at the higher acid concentrations. Although with $120 \mathrm{mM}$ it was still possible to detect this inhibition, it occurred in a very small sub-population, more than $99.86 \%$ of the cells remaining non-viable regardless of the presence of cycloheximide.

The mode of programmed cell death under acetic acid stress conditions was further characterized by the examination of cell death markers that are typical of apoptosis. The evidence obtained indicates that acetic 
acid, like $\mathrm{H}_{2} \mathrm{O}_{2}$ (Madeo et al., 1999), can trigger an apoptotic phenotype in $S$. cerevisiae. The following concentration-dependent changes were observed after treatment with acetic acid: chromatin condensation along the nuclear envelope, exposure of phosphatidylserine at the outer surface of the yeast cytoplasmic membrane and formation of DNA strand breaks. The nuclear ultrastructural changes were significantly reduced when the treatment was carried out in the presence of cycloheximide, reinforcing our interpretation about the active nature of cell death induced by the lower concentration of acetic acid.

Even though a very small population with apoptotic markers was detected at $120 \mathrm{mM}$, the present results suggest that a non-active (necrotic) process is the predominant cell death mechanism in samples exposed for $200 \mathrm{~min}$ to acetic acid at concentrations above $80 \mathrm{mM}$. This interpretation is based on the following points: (i) mortality at $120 \mathrm{mM}$ (or more) is not significantly inhibited by cycloheximide; (ii) the percentage of cells with apoptotic markers, induced by increasing concentrations of acid, increases with treatments up to $80 \mathrm{mM}$ acid and then decreases; (iii) the percentage of cells with ultrastructural alterations typical of necrosis is highest and very extensive in samples treated with $120-160 \mathrm{mM}$ acid. An apoptotic or necrotic phenotype was also reported for $S$. cerevisiae exposed for $200 \mathrm{~min}$ to low or high concentrations of $\mathrm{H}_{2} \mathrm{O}_{2}$, respectively (Madeo et al., 1999).

Our data regarding the structural/morphological markers of apoptosis showed that the proportion of yeast cells with chromatin condensation induced by $40 \mathrm{mM}$ acetic acid was higher than the proportion of cells exhibiting surface exposure of phosphatidylserine [annexin $\mathrm{V}(+)$, PI $(-)$ ] and DNA cleavage (TUNELpositive). This observation indicates that, in our model, nuclear chromatin alteration precedes both phosphatidylserine exposures at the cytoplasmic membrane surface and significant endonuclease DNA cleavage. Similar observations have been reported in other models of apoptosis, i.e. chromatin condensation preceding DNA cleavage (Sun et al., 1994) and phosphatidylserine exposure (Darzynkiewicz et al., 1997).

The yeast $S$. cerevisiae has been used as a host to express proteins of the Bcl-2 family and hence to study the mechanisms underlying apoptosis in higher eukaryotes. Up to now, only one instance of an active cell death process in yeasts, independent of heterologous expression of pro-apoptotic proteins, has been reported, namely programmed cell death due to exposure of $S$. cerevisiae to $\mathrm{H}_{2} \mathrm{O}_{2}$ (Madeo et al., 1999). In the present work, we have shown that the apoptotic phenotype in $S$. cerevisiae can also be induced by acetic acid, pointing to the possibility that this mode of cell death may be more generalized in yeasts and extended to other stress agents. It is known that ROS play a central role in the regulation of apoptosis at various levels (Madeo et al., 1999). Further studies are in progress in order to evaluate ROS production in S. cerevisiae under the conditions where programmed cell death induced by acetic acid was detected. This would show if commitment of $S$. cerevisiae to a programmed cell death process in response to acetic acid is also mediated through a ROSdependent apoptotic pathway.

\section{ACKNOWLEDGEMENTS}

The authors are grateful to Mrs Paula Macedo and Professor Jorge Pedrosa for expert assistance in the electron microscopy analysis and in the TUNEL assay, respectively. P.L. has a fellowship from PRAXIS XXI (Fundação da Ciência e Tecnologia, Portugal).

\section{REFERENCES}

Ameisen, J. C. (1996). The origin of programmed cell death. Science 272, 1278-1279.

Barnett, J. A., Payne, R. W. \& Yarrow, D. (2000). Yeasts: Characteristics and Identification, 3rd edn. Cambridge: Cambridge University Press.

Byers, B. \& Goetsch, L. (1991). Preparation of yeast cells for thinsection electron microscopy. Methods Enzymol 194, 602-608.

Cássio, F., Leão, C. \& van Uden, N. (1987). Transport of lactate and other short-chain monocarboxylates in the yeast Saccharomyces cerevisiae. Appl Environ Microbiol 53, 509-513.

Cerbón, J. \& Calderón, V. (1991). Changes of the compositional asymmetry of phospholipids associated to the increment in the membrane surface potential. Biochim Biophys Acta 1067, 139-144.

Darzynkiewicz, Z., Juan, G., Li, X., Gorczyca, W., Murakami, T. \& Traganos, F. (1997). Cytometry in cell necrobiology: analysis of apoptosis and accidental cell death (necrosis). Cytometry 27, $1-20$.

Hiraoka, W., Fuma, K. \& Kuwabara, M. (1997). Concentrationdependent modes of cell death in Chinese hamster V79 cells after treatments with $\mathrm{H}_{2} \mathrm{O}_{2}$. J Radiat Res Tokyo 38, 95-102.

Komatsu, K., Hopkins, K. M., Lieberman, H. B. \& Wang, H. (2000). Schizosaccharomyces pombe $\mathrm{Rad} 9$ contains a BH3-like region and interacts with the anti-apoptotic protein Bcl-2. FEBS Lett 481, 122-126.

Leão, C. \& van Uden, N. (1986). Transport of lactate and other short-chain monocarboxylates in the yeast Candida utilis. Appl Microbiol Biotechnol 23, 389-393.

Lewis, K. (2000). Programmed death in bacteria. Microbiol Mol Biol Rev 64, 503-514.

Ligr, M., Madeo, F., Frohlich, E., Hilt, W., Frohlich, K. U. \& Wolf, D. H. (1998). Mammalian Bax triggers apoptotic changes in yeast. FEBS Lett 438, 61-65.

Longo, V. D., Ellerby, L., Bredesen, D., Valentine, J. \& Gralla, E. (1997). Human Bcl-2 reverses survival defects in yeast lacking superoxide dismutase and delays death of wild-type yeast. J Cell Biol 137, 1581-1588.

Ludovico, P. (1999). Efeitos do ácido acético no potencial de membrana mitocondrial e sua relação com a perda de integridade e viabilidade celular em Zygosaccharomyces bailii e Saccharomyces cerevisiae. Master thesis, Universidade do Minho, Braga, Portugal.

Madeo, F., Fröhlich, E. \& Fröhlich, K. U. (1997). A yeast mutant showing diagnostic markers of early and late apoptosis. J Cell Biol 139, 729-734. 
Madeo, F., Frohlich, E., Ligr, M., Grey, M., Sigrist, S. J., Wolf, D. H. \& Frohlich, K. U. (1999). Oxygen stress: a regulator of apoptosis in yeast. J Cell Biol 145, 757-767.

Martin, S. J., Reutelingsperger, C. P. M., McGahon, A. J., Rader, J. A., van Schie, R. C. A. A., LaFace, D. M. \& Green, D. R. (1995). Early redistribution of plasma membrane phosphatidylserine is a general feature of apoptosis regardless of the initiating stimulus: inhibition by overexpression of Bcl-2 and Abl. J Exp Med 182, 1545-1556.

Matsuyama, S., Nouraini, S. \& Reed, J. (1999). Yeast as a tool for apoptosis research. Curr Opin Microbiol 2, 618-623.

Naito, T., Kusano, K. \& Kobayashi, I. (1995). Selfish behavior of restriction-modification systems. Science 267, 897-899.

Pampulha, M. E. \& Loureiro, V. (1989). Interaction of the effects of acetic acid and ethanol on inhibition of fermentation in Saccharomyces cerevisiae. Biotechnol Lett 11, 269-274.

Pinto, I., Cardoso, H. \& Leão, C. (1989). High enthalpy and low enthalpy death in Saccharomyces cerevisiae induced by acetic acid. Biotechnol Bioeng 33, 1350-1352.

Prudêncio, C., Sansonetty, F. \& Côrte-Real, M. (1998). Flow cytometric assessment of cell structural and functional changes induced by acetic acid in the yeasts Zygosaccharomyces bailii and Saccharomyces cerevisiae. Cytometry 31, 307-313.
Sánchez, A., Álvarez, A. M., Benito, M. \& Fabregat, I. (1997). Cycloheximide prevents apoptosis, reactive oxygen species production, and glutathione depletion induced by transforming growth factor $\beta$ in fetal rat hepatocytes in primary culture. Hepatology 26, 935-943.

Skulachev, V. P. (1999a). Phenoptosis: programmed death of an organism. Biochemistry (Moscow) 64, 1418-1426.

Skulachev, V. P. (1999b). Mitochondrial physiology and pathology; concepts of programmed death of organelles, cells and organisms. Mol Asp Med 20, 139-184.

Skulachev, V. P. (2000). Mitochondria in the programmed death phenomena; a principle of biology: "it is better to die than to be wrong”. IUBMB Life 49, 365-373.

Sun, X.-M., Snowden, R. T., Dinsdale, D., Ormerod, M. \& Cohen, G. (1994). Changes in nuclear chromatin precede internucleosomal DNA cleavage in induction of apoptosis by etoposide. Biochem Pharmacol 47, 187-195.

Yarmolinsky, M. B. (1995). Programmed cell death in bacterial populations. Science 267, 836-837.

Received 29 January 2001; revised 26 March 2001; accepted 14 May 2001. 